\title{
Electroacupuncture at the ST36 acupoint increases interleukin-4 responsiveness in macrophages, generation of alternatively activated macrophages and susceptibility to Leishmania major infection
}

Danillo N Aguiar*, Mayara M Silva, Walki V Parreira, Fernanda D Tome, Lucas F Batista, Clayson M Gomes and Milton AP Oliveira

\begin{abstract}
Background: Electroacupuncture (EA) has been used to treat inflammatory diseases. Alternatively activated macrophages (AAMo) stimulated by cytokines such as interleukin (IL)-4, IL-10 and IL-13 are anti-inflammatory and mildly microbicidal. This study aimed to evaluate whether EA at the Zusanli acupoint (ST36) would change the profile of healthy murine macrophages, particularly the generation of AAMo and susceptibility to Leishmania major infection.

Methods: BALB/c mice were treated with EA $(15 / 30 \mathrm{~Hz})$ at the ST36 acupoint for $20 \mathrm{~min} / \mathrm{d}$ for $5 \mathrm{~d}$. After the final EA session, the mice were euthanized and their peritoneal cells were harvested and counted for determination of arginase activity, nitric oxide (NO) production and microbicidal activity after culture in the presence or absence of IL-4, interferon-y (IFNY) or lipopolysaccharide (LPS) or both IFNy and LPS. Twelve mice were infected with L. major promastigotes into the footpads after the final EA session and the infection course was monitored.

Results: Peritoneal cells freshly obtained from EA-treated mice had similar arginase and microbicidal activities to cells from sham-treated mice. After culture with IL-4, cells from EA-treated mice exhibited significant increases in the arginase activity (sham: $58 \pm 11.3$ vs. EA: $80.7 \pm 4.6 \%, P=0.025$ ) and number of parasites/infected cell (sham: $2.5 \pm 0.4$ vs. EA: $4.3 \pm 0.8$ cells, $P=0.007$ ). The NO production was lower in cells from EA-treated mice cultured in the presence of a combination of IFNY and LPS (sham: $31.6 \pm 6.5 \mathrm{vs}$. EA: $22.3 \pm 2.1 \mu \mathrm{M}, P=0.025)$. The lesion size in mice infected with L. major promastigotes was larger in EA-treated mice (sham: $3.26 \pm 0.29$ vs. EA: $2.23 \pm 0.4 \mathrm{~mm}$, $P=0.039$ ).
\end{abstract}

Conclusion: EA at the ST36 acupoint increases IL-4 responsiveness in macrophages, Generation of AAMo and susceptibility to L. major infection

\footnotetext{
* Correspondence: dnafisio@yahoo.com.br

Department of Microbiology, Immunology, Parasitology and Pathology,

Tropical Pathology and Public Health Institute, Federal University of Goiás,

Goiânia, Goiás, Brazil
} 


\section{Background}

A number of observations on the anti-inflammatory actions of acupuncture have been published for various acupoints, acupuncture frequencies and additional application of electrostimulation [1]. The insertion of a needle into an acupoint induces the release of pro-inflammatory mediators such as substance P, calcitonin gene-related peptide, histamine, bradykinin, serotonin, proteases, pro-inflammatory cytokines and others, thereby causing vasodilatation and producing danger signals that are transmitted via the afferent vagus nerve [1-3]. In response to these stimuli, the hypothalamus secretes corticotropin-releasing hormone $(\mathrm{CRH})$, which leads to a decrease in pro-inflammatory cytokines and an increase in anti-inflammatory cytokines such as interleukin (IL)-10 [3]. Leukocytes also respond to $\mathrm{CRH}$ and secrete anti-inflammatory cytokines [4].

It has been shown that electrical stimulation of the ST36 acupoint significantly reduces both the serum and tissue levels of the pro-inflammatory cytokines such as tumor necrosis factor (TNF) in rats with ulcerative colitis [5], chronic inflammation induced by Freund's complete adjuvant [6], experimental arthritis $[7,8]$, inflammation induced by carrageenan injection [9] and other conditions. Furthermore, alternatively activated macrophages (AAMo) are associated with the improvement of several inflammatory diseases, such as experimental arthritis [10] and colitis [11].

Corticoids and IL-10 act on macrophages and increase the generation of AAMo [12,13]. AAMo are mainly induced after stimulation with IL-4 and IL-13, and produces cytokines and enzymes for inflammation modulation and initiation of wound healing [12,13]. The properties of AAMo depend on their arginase activity [14], which increases ornithine and urea production. Ornithine can be metabolized to collagen or purine, which are both fundamental for wound healing as described before [12-14]. In addition, AAMo are more susceptible to intracellular pathogens such as Leishmania major [15].

Classically activated macrophages (cMO) are induced by interferon- $\gamma$ (IFN $\gamma$ ) and produce nitric oxide (NO) through induced NO synthase (iNOS) to enhance the resistance to intracellular pathogens such as $L$. major $[13,16]$. Therefore, cMO are able to control the growth of intracellular pathogens, while AAMo are susceptible to infection with such pathogens, both in vitro and in vivo [15-17].

This study aims to evaluate whether electroacupuncture (EA) at the Zusanli acupoint (ST36) would change the profile of healthy murine macrophages, particularly the generation of AAMo and susceptibility to L. major infection.

\section{Methods}

Animals

Female BALB/c mice (weighing 18-22 g) were supplied by the Animal Care Facility of the Institute of Tropical Pathology of the Federal University of Goiás, and divided into two groups of three animals each. The experiments were triplicated. The mice were housed under controlled lighting conditions (12-h/12-h light/dark cycle with lights on at 7:00 am) at room temperature with free access to water and food. The Human and Animal Research Committee of the Clinical Hospital of Federal University of Goiás approved all procedures on these animals (Approval Protocol 023/2009).

\section{EA treatment}

Before manipulation with EA, the mice were acclimated to the restraint for one week. The ST36 acupoint is located at the anterior tibial muscle, $5 \mathrm{~mm}$ lateral to and below the anterior tubercle of the tibia $[18,19]$. The mice were treated daily with EA for 5 or $10 \mathrm{~d}$. For the EA treatment, the mice were immobilized in a plastic cylinder that allowed access to the ST36 acupoint. Two stainless-steel needles $(0.18 \times 8 \mathrm{~mm})$ were inserted (3 $\mathrm{mm}$ deep) into the ST36 acupoint. The anode and cathode leads from an electrical stimulator (WQ IOD1; Donghua, China) were connected to the two acupuncture needles. The current, a faradic, bipolar and asymmetrical wave with an intensity range of 4-6 mA, was applied for $20 \mathrm{~min}$ with increases in a stepwise manner. The stimulation frequency was alternated between 15 and $30 \mathrm{~Hz}(15 / 30 \mathrm{~Hz})$. The intensity of the stimulation was determined by the minimum voltage required to cause moderate muscle contraction. The sham group of mice received only needle insertion into a non-acupoint area in the gluteal muscle without electrical stimulation. The mice were euthanized by decapitation immediately after the final EA treatment.

\section{Peritoneal cells}

Resident macrophages were obtained by peritoneal cavity washing with $5 \mathrm{~mL}$ of sterile phosphate-buffered saline (PBS). Following aspiration of the fluid, a suspension of the cells was washed twice with PBS and centrifuged at $300 \times g$ for $10 \mathrm{~min}$. The suspension was examined in a Neubauer chamber, counted and after adjustment of the concentration to $1 \times 10^{6}$ peritoneal cells for arginase activity analyses and $2 \times 10^{5}$ peritoneal cells for NO and microbicidal assays. The cells were cultured in 24-well plates (TPP, Switzerland) in $0.5 \mathrm{~mL}$ of RPMI 1640 medium (Sigma Chemical Co., USA) supplemented with $10 \%$ fetal calf serum (FCS; Cripion, Brazil), $2 \mathrm{mM}$ L-glutamine (Sigma Chemical Co. USA), $10 \mathrm{mM}$ Hepes (Sigma Chemical Co. USA), $100 \mathrm{U} / \mathrm{mL}$ penicillin (Sigma Chemical Co. USA) and $100 \mu \mathrm{g} / \mathrm{mL}$ streptomycin 
(Sigma Chemical Co. USA). The cells in the supplemented RPMI medium were incubated at $36^{\circ} \mathrm{C}$ under $5 \%$ $\mathrm{CO}_{2}$ in the presence or absence of $1 \mu \mathrm{g} / \mathrm{mL}$ lipopolysaccharide (LPS; Escherichia coli O111:B4; Sigma Chemical Co. USA), 5 or $25 \mathrm{ng} / \mathrm{mL}$ IL-4 (R\&D Systems, USA) or $5 \mathrm{ng} / \mathrm{mL}$ IFNY (R\&D Systems, USA). The combination of $1 \mu \mathrm{g} / \mathrm{mL}$ LPS and $2 \mathrm{ng} / \mathrm{mL}$ IFNY was used to evaluate NO production. After $48 \mathrm{~h}$ of culture, the supernatant was harvested for the NO analysis, and the cells were subjected to the arginase assay.

\section{Arginase assay}

Peritoneal cells obtained before or after culture were washed twice with PBS and then centrifuged at $300 \times g$ for $10 \mathrm{~min}$. The cell pellets $\left(1 \times 10^{6}\right.$ cells $)$ were resuspended in $50 \mu \mathrm{L}$ of lysis buffer comprising $50 \mathrm{mM}$ Tris$\mathrm{HCl}(\mathrm{pH}$ 7.5), $0.1 \mathrm{mM}$ EDTA, 0.1\% (v/v) Triton X-100 and $0.5 \%(\mathrm{v} / \mathrm{v})$ protease inhibitor cocktail (Sigma Chemical Co., USA). The arginase activity was determined by urea production using a previously described method [20] with some modifications. Briefly, the cell lysate $(50 \mu \mathrm{l})$ was added to $50 \mu \mathrm{L}$ of $50 \mathrm{mM}$ Tris- $\mathrm{HCl}$ buffer $(\mathrm{pH}$ 7.5) containing $10 \mathrm{mM} \mathrm{MnCl} 2$ (Vetec, Brazil). Macrophage arginase was activated by heating the mixture to $60^{\circ} \mathrm{C}$ for $10 \mathrm{~min}$. The hydrolysis reaction of Larginine by arginase was carried out by incubating the lysate with $50 \mu \mathrm{L}$ of $0.5 \mathrm{ML}$-arginine (pH 9.7; Sigma Chemical Co., USA) at $37^{\circ} \mathrm{C}$ for $1 \mathrm{~h}$. The amount of urea production was determined with an enzymatic UREA500 ${ }^{\circledR}$ assay kit (Doles, Brazil) according to the manufacturer's instructions. The results were expressed as $\mathrm{mg} / \mathrm{dL}$ urea based on a standard curve established with known concentrations of urea.

\section{Determination of NO production}

NO production was estimated by determining the concentration of nitrite in the supernatant of peritoneal cell cultures with or without LPS stimulation using the Griess method [21]. The culture supernatant $(100 \mu \mathrm{L})$ was incubated with an equal volume of Griess reagent (1.0\% sulfanilamide, $0.1 \%$ naphazoline hydrochloride, $2.5 \%$ orthophosphoric acid; Vetec, Brazil) for $10 \mathrm{~min}$ at room temperature. The absorbance at $540 \mathrm{~nm}$ was determined using a microplate reader (Multiskan; Thermo Labsystems, Finland). The results were expressed as $\mu \mathrm{M}$ nitrite based on a standard curve established with known concentrations of sodium nitrite (Vetec, Brazil) dissolved in culture medium.

Mouse infection and assessment of leishmanicidal activity Promastigotes of L. major (clone, MHOM/IL/80/Friedlin; kindly provided by Dr Leda Vieira, Brazil) at $1 \times 10^{5}$ promastigotes $/ \mathrm{mL}$ were cultured in 24-well plates and passed every $2 \mathrm{~d}$. The culture was performed in Grace's
Insect Medium (Sigma Chemical Co., USA) supplemented with inactivated 20\% FCS (Cripion, Brazil), $2 \mathrm{mM} \mathrm{L-}$ glutamine (Sigma Chemical Co., USA), $100 \mathrm{U} / \mathrm{mL}$ penicillin (Sigma Chemical Co., USA) and $100 \mu \mathrm{g} / \mathrm{mL}$ streptomycin (Sigma Chemical Co., USA). Parasites in the stationary growth phase were harvested at $5 \mathrm{~d}$ after the beginning of culture and washed three times in PBS before use. For assessment of leishmanicidal activity, $1 \times 10^{7}$ parasites were injected into the peritoneal cavity of sham- or EA-treated mice. After $3 \mathrm{~h}$, the mice were euthanized by decapitation and peritoneal cells were collected by peritoneal washing with PBS. For removal of polymorphonuclear cells and non-phagocytosed parasites, the cell suspension was centrifuged at $700 \times g$ for 15 min at $20^{\circ} \mathrm{C}$ using Lymphoprep ${ }^{\circledR}$ (Sigma Chemical Co., USA) and washed twice with PBS before culture. Slides of the cells were prepared before and after $48 \mathrm{~h}$ of culture in the presence or absence of IL- 4 or IFNy. The slides were stained with an Instant Prov Kit (Newprov, Brazil) for subsequent quantification of the infected cells under a light microscope. In monitoring of the infection course, $1 \times 10^{6}$ parasites were injected into the left footpad of sham- or EA-treated mice. Footpad swelling was measured weekly using a dial thickness gauge (Mitutoyo, Japan), and the thickness increase was calculated as the difference between the left and right footpad measurements.

\section{Expression of IL-4 receptor in macrophages}

Peritoneal cells were washed twice with PBS and resuspended at $2 \times 10^{5}$ cells $/ 50 \mu \mathrm{L}$ of PBS containing $3 \%$ normal goat serum (NGS). A purified anti-IL-4 receptor antibody ( $1 \mu \mathrm{L} / \mathrm{mL}$; Genzyme, USA) was added to the cells and incubated for $30 \mathrm{~min}$ at $25^{\circ} \mathrm{C}$. After two washes with PBS, the cells were resuspended in $50 \mu \mathrm{L}$ of PBS containing 3\% NGS. Next, $5 \mu \mathrm{L}$ of FITC-conjugated goat anti-rat antibody (Serotec Ltd., UK) was added at 1:10 dilution and the cells were incubated for $20 \mathrm{~min}$ at $25^{\circ} \mathrm{C}$. The cells were washed twice with PBS and resuspended in $50 \mu \mathrm{L}$ of PBS containing 3\% NGS. After addition of $10 \mu \mathrm{L}$ of an anti-CD11b APC antibody $(0.01 \mathrm{mg} / \mathrm{mL}$; BD Biosciences, USA), the cells were incubated for $20 \mathrm{~min}$ at $25^{\circ} \mathrm{C}$. Cells were acquired using a C6 Accuri Flow Cytometer (Accuri Cytometers, USA) and analyzed with FCS Express 4 Plus Research Edition software (Denovo Software, USA). The surface expression of IL-4 receptor was quantified as a measure of the mean fluorescence intensity in $\mathrm{CD}_{11 \mathrm{~b}^{+}}$cells.

\section{Statistical analysis}

All experiments were triplicated except the infection course experiments, which were duplicated. Unless specified otherwise, the data were expressed as the mean \pm standard deviation (SD) of all replicated experiments. 
The data for NO production were expressed as the mean $\pm S D$ of a representative experiment of the three experiments, owing to high variability in the basal levels. The statistical significance of differences between groups was determined by the Student's $t$-test (two groups), one-way ANOVA followed by a Tukey test (multiple groups) and two-way ANOVA followed by a Tukey test (infection course curve) using Graph Pad 4.0 software (GraphPad Inc., USA). The results were considered statistically significant at $P<0.05$.

\section{Results}

\section{IL-4 responsiveness of peritoneal macrophages}

Correct EA treatment and insertion of needles in the ST36 acupoint were recognized by the characteristic rhythmic dorsiflexion of the stimulated hind limb, which was observed in all EA-treated mice. At the end of the final EA treatment, the mice were immediately euthanized and their peritoneal cells were harvested for analysis. The numbers of cells recovered from the peritoneal
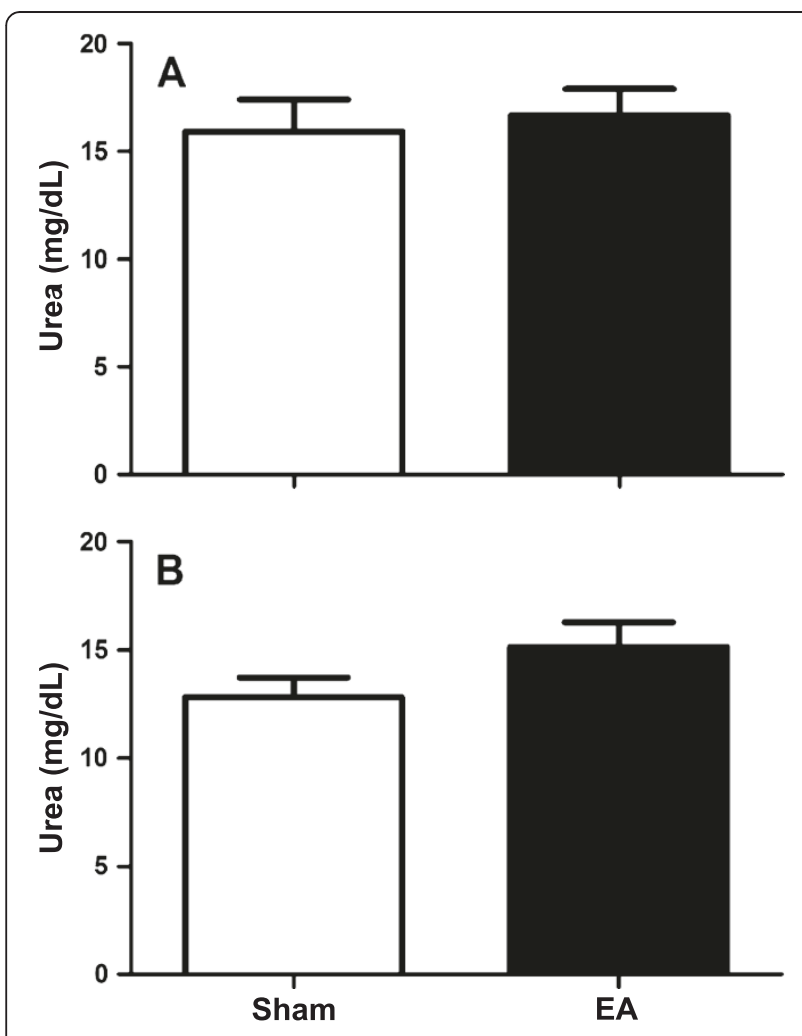

Figure 1 Arginase activity in cells harvested from the peritoneal cavity of EA-treated mice. Mice were treated with EA $(15 / 30 \mathrm{~Hz})$ at the Zusanli acupoint (ST36) for $20 \mathrm{~min} / \mathrm{d}$ for $5 \mathrm{~d}$ (A) or $10 \mathrm{~d}$ (B). After the final EA session, the mice were euthanized and their peritoneal cells were harvested for evaluation by the arginase assay. The data are represented as mean \pm SD of urea production per lysate of $1 \times 10^{6}$ cells. The sham-treated mice received only needle insertion into a non-acupoint (gluteal muscle) without electrical stimulation. There were nine mice in each group.
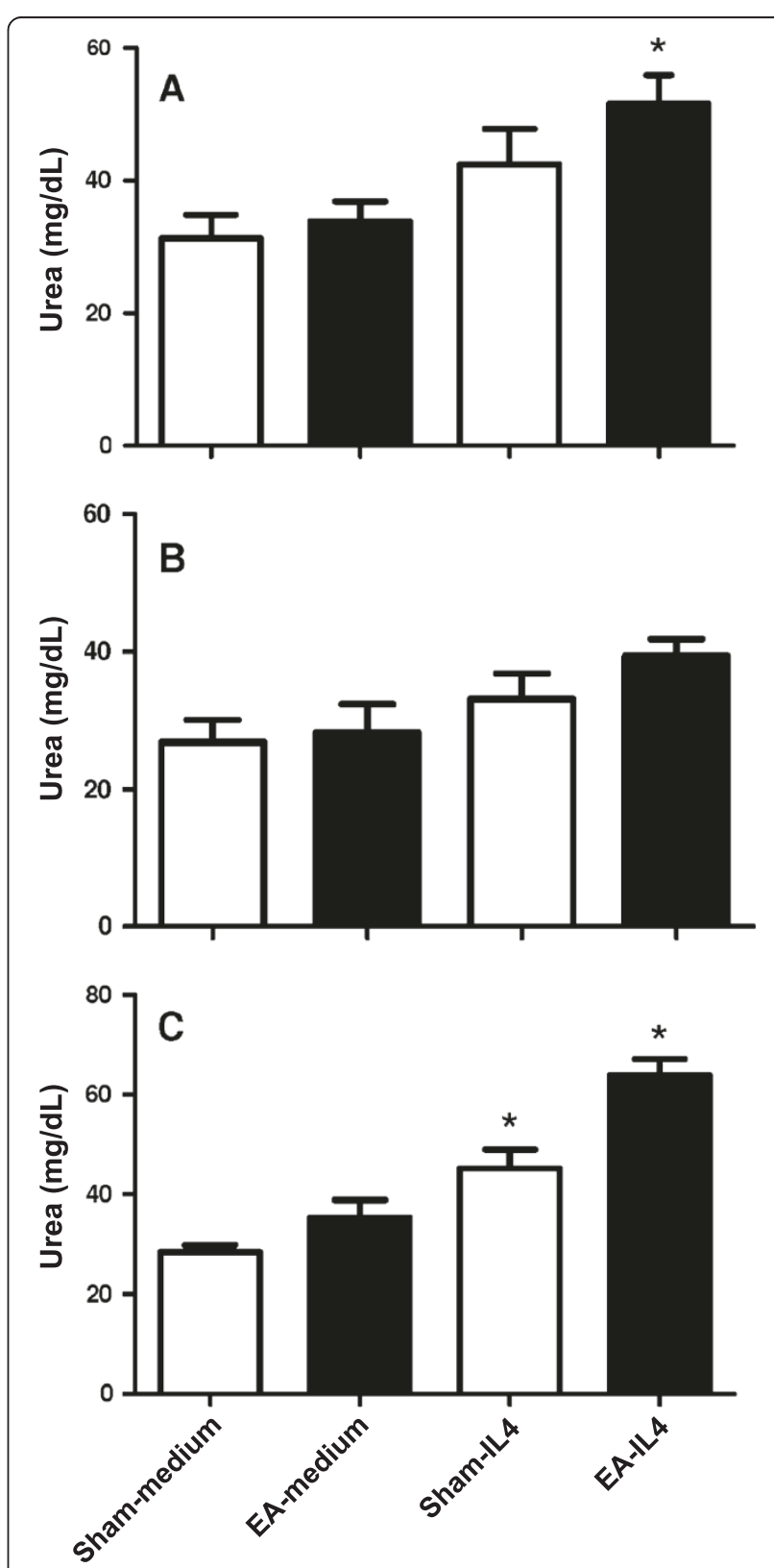

Figure 2 Arginase activity in cells harvested from the peritoneal cavity of EA-treated mice after culture in the presence of IL-4. Mice were treated with EA $(15 / 30 \mathrm{~Hz})$ at the Zusanli acupoint (ST36) for $20 \mathrm{~min} / \mathrm{d}$ for $5 \mathrm{~d}$ (A and C) or $10 \mathrm{~d}$ (B). After the final EA session, the mice were euthanized and their peritoneal cells were harvested and cultured in the absence (medium) or presence of $\mathrm{IL}-4$ at $5 \mathrm{ng} / \mathrm{mL}$ ( $A$ and B) or $25 \mathrm{ng} / \mathrm{mL}$ (C). After $48 \mathrm{~h}$, the culture medium was discarded, and the cells were lysed for evaluation by the arginase assay. The data are represented as mean \pm SD of urea production per lysate of $1 \times 10^{6}$ cells. The sham-treated mice received only needle insertion into a nonacupoint (gluteal muscle) without electrical stimulation. There were nine mice in each group. ${ }^{*} \mathrm{P}<0.05$, significant difference between sham- and EA-treated mice under the same culture conditions by Student's t-test. 
cavity were similar between the two groups (sham: $2.72 \pm 0.5 \times 10^{6}$ vs. EA: $3.01 \pm 0.6 \times 10^{6}$ cells/mouse, $P=0.08)$. The arginase enzyme activities were also similar between the two groups $(P=0.34)$, with urea production ranging from 10.6 to $21.3 \mathrm{mg} / \mathrm{dL}$ per $1 \times 10^{6}$ peritoneal cells in each group (Figure 1A). The arginase activities of peritoneal cells were similar for EA- and sham-treated

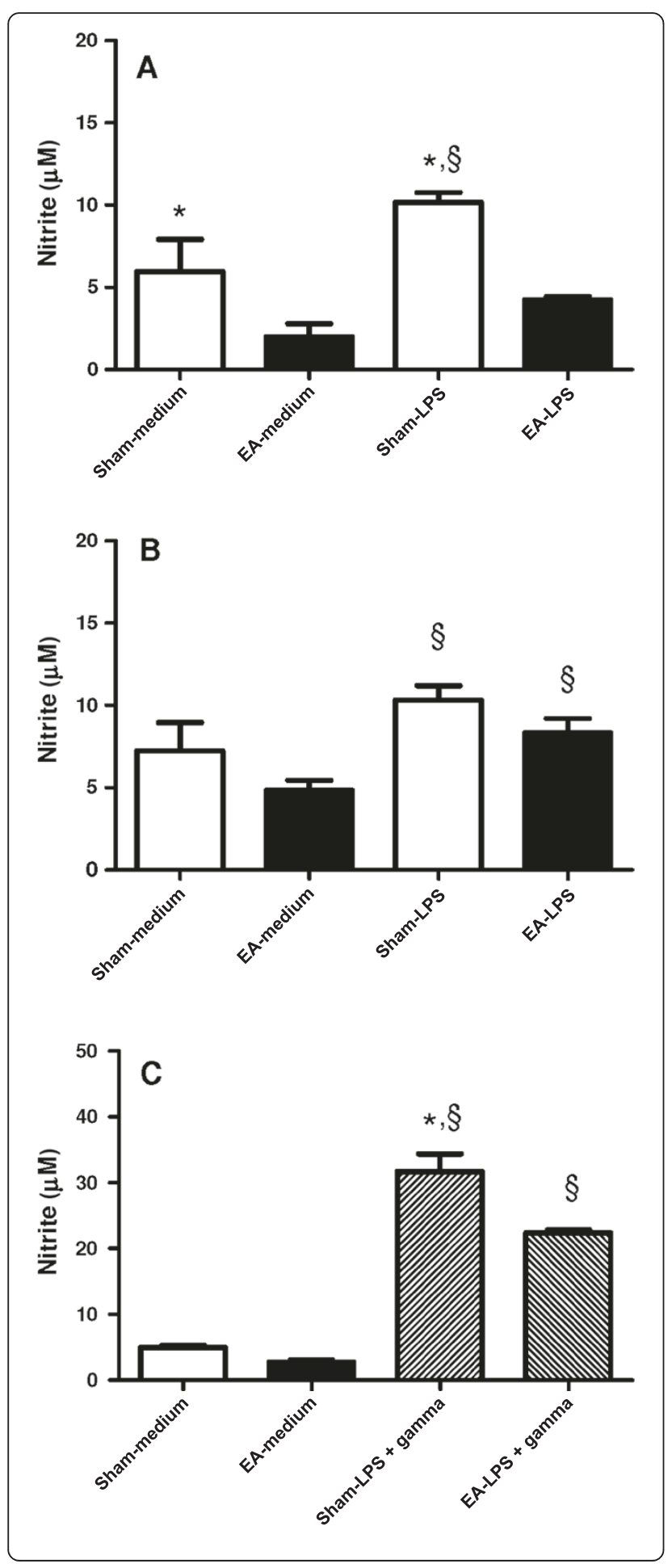

Figure 3 NO production by cells harvested from the peritoneal cavity of EA-treated mice. BALB/C mice were treated with EA (15/ $30 \mathrm{~Hz}$ ) at the Zusanli acupoint (ST36) for $20 \mathrm{~min} / \mathrm{d}$ for $5 \mathrm{~d}$ (A and C) or $10 \mathrm{~d}$ (B). After the final EA session, the mice were euthanized and their peritoneal cells were harvested and cultured in the absence or presence of $1 \mu \mathrm{g} / \mathrm{mL}$ LPS (A and B) or $1 \mu \mathrm{g} / \mathrm{mL}$ LPS and $2 \mathrm{ng} / \mathrm{mL}$ IFNy (C). After $48 \mathrm{~h}$, the culture medium was harvested for nitrite measurement by the Griess assay. The data are represented as mean \pm SD of the increase in nitrite production after LPS stimulation. The sham-treated mice received only needle insertion into a nonacupoint (gluteal muscle) without electrical stimulation. The data presented are representative of one of three independent experiments containing three mice in each group. ${ }^{*} P<0.05$, significant difference between sham- and EA-treated mice under the same culture conditions by Student's t-test; $\S P<0.05$, significant difference between cells from the same mouse group under different culture conditions by Student's t-test.

mice for both $5 \mathrm{~d}(\mathrm{P}=0.34)$ and $10 \mathrm{~d} \quad(\mathrm{P}=0.09)$ (Figure $1 \mathrm{~A}$ and $1 \mathrm{~B})$.

When the peritoneal cells were cultured for $48 \mathrm{~h}$, urea production was increased (reaching $31.3 \pm 7.1 \mathrm{mg} / \mathrm{dL}$ ), indicating an increase in arginase activity. However, the activities in cells from both sham- and EA-treated mice were maintained at similar levels $(\mathrm{P}=0.30$ and $\mathrm{P}=0.41$, Figure $2 \mathrm{~A}$ and $\mathrm{B}$, respectively). Since IL-4 has the ability to promote the generation of AAMo by increase arginase activity [12], we examined whether IL-4 had a different effect on the arginase activity in cells from EAtreated mice. Urea production by peritoneal cells increased from $31.3 \pm 7.1$ to $42.5 \pm 10.7 \mathrm{mg} / \mathrm{dL}$ (increase of $35.6 \%)$ in cells from sham-treated mice in the presence of IL-4 compared with cells cultured without IL-4 $(\mathrm{P}=0.058$; Figure $2 \mathrm{~A})$. Urea production increased from $33.8 \pm 5.9$ to $51.6 \pm 8.6 \mathrm{mg} / \mathrm{dL}$ (increase of $52.2 \%$ ) in EAtreated mice after IL- 4 treatment $(\mathrm{P}=0.011$; Figure $2 \mathrm{~A})$, suggesting an increase of the number of AAMo. Although the increase in IL-4 responsiveness was not significant after $10 \mathrm{~d}$ of treatment $(\mathrm{P}=0.052)$, the profile of higher IL-4 responsiveness was maintained in the EAtreated mice (Figure 2B). In another experiment performed with a higher dose of IL-4, urea production was increased by $58 \%(\mathrm{P}=0.037)$ in peritoneal cells from sham-treated mice and by $80.7 \%(\mathrm{P}=0.025)$ in peritoneal cells from EA-treated mice (Figure 2C). The latter data show that the higher responsiveness to IL-4 was not related to the IL- 4 dose.

\section{NO production}

Arginase converts L-arginine to urea, which is the substrate used by iNOS to produce NO in cMO. For evaluation of the NO production by macrophages obtained from EA-treated mice, peritoneal cells were cultured in the presence of LPS or LPS and IFN $\gamma$. The NO production by cells from sham-treated mice was significantly 
higher than the NO production by cells from EA-treated mice $(P=0.046)$ (Figure $3 \mathrm{~A})$. This difference was not significant in the mice treated for $10 \mathrm{~d}(\mathrm{P}=0.143)$ (Figure 3B). Although LPS stimulation significantly increased the NO production (sham vs. sham-LPS: $\mathrm{P}=0.048$; EA vs. EA-LPS: $\mathrm{P}=0.006$ ) (Figure $3 \mathrm{~B}$ ), the classical activation of macrophages depends on IFNY stimulus [13]. As shown in Figure 3C, IFNY augmented the NO production stimulated by LPS. The NO production in cells from EA-treated mice was significantly lower than that in cells from sham-treated mice $(\mathrm{P}=0.025)$.

L. major survival in IL-4-activated peritoneal macrophages Activation of iNOS or arginase in macrophages is essential for controlling the growth of the intracellular parasite L. major. Since our data suggested that EA favors the activation of arginase over iNOS, we investigated whether macrophages obtained from EA-treated mice had a decreased ability to kill L. major. Mice were injected intraperitoneally with live L. major promastigotes, and euthanized after $3 \mathrm{~h}$ to obtain peritoneal cells. The phagocytosis of parasites by macrophages obtained at $3 \mathrm{~h}$ after L. major injection was similar between sham- and EA-treated mice $(P=0.271$; Figure $4 \mathrm{~A}$, w/o culture). Culture of the infected cells for $48 \mathrm{~h}$ without IL-4 or IFNy led to similar percentages of infected cells and amounts of parasites inside the macrophages between the macrophages from sham- and EA-treated mice $(\mathrm{P}=0.84$ and $\mathrm{P}=0.601$, respectively). However, there was an increase in the percentage of infected macrophages in the presence of IL-4 (sham vs. sham-IL4: $\mathrm{P}=0.013$; $\mathrm{EA}$ vs. EA-IL-4: $\mathrm{P}=0.029$; Figure $4 \mathrm{~A}$ ). Macrophages from EA-treated mice stimulated with IL4 showed an increase in the number of parasites per infected cell (sham: $2.5 \pm 0.4$ vs. EA: $4.3 \pm 0.8 ; \mathrm{P}=0.007$; Figure 4B), suggesting that these macrophages were more susceptible to L. major infection. The presence of parasites inside the macrophages is depicted in Figure 4C.

\section{Expression of IL-4 receptor in macrophages}

Since the IL-4 responsiveness was increased in macrophages after EA, we investigated IL-4 receptor expression in the peritoneal cells from sham- or EA-treated mice. IL-4 receptor expression was detected in $80 \%$ of macrophages $\left(\mathrm{CD} 11 \mathrm{~b}^{+}\right.$) from both groups (Figure $5 \mathrm{~B}, \mathrm{D}$ and $E$ ), with no significant difference in the percentages of expression between the two groups $(P=0.273)$. The mean fluorescence intensities of the IL-4 receptor expression in $\mathrm{CD}_{11} \mathrm{~b}^{+}$cells were similar in the sham- and EA-treated mice $(\mathrm{P}=0.515)$.

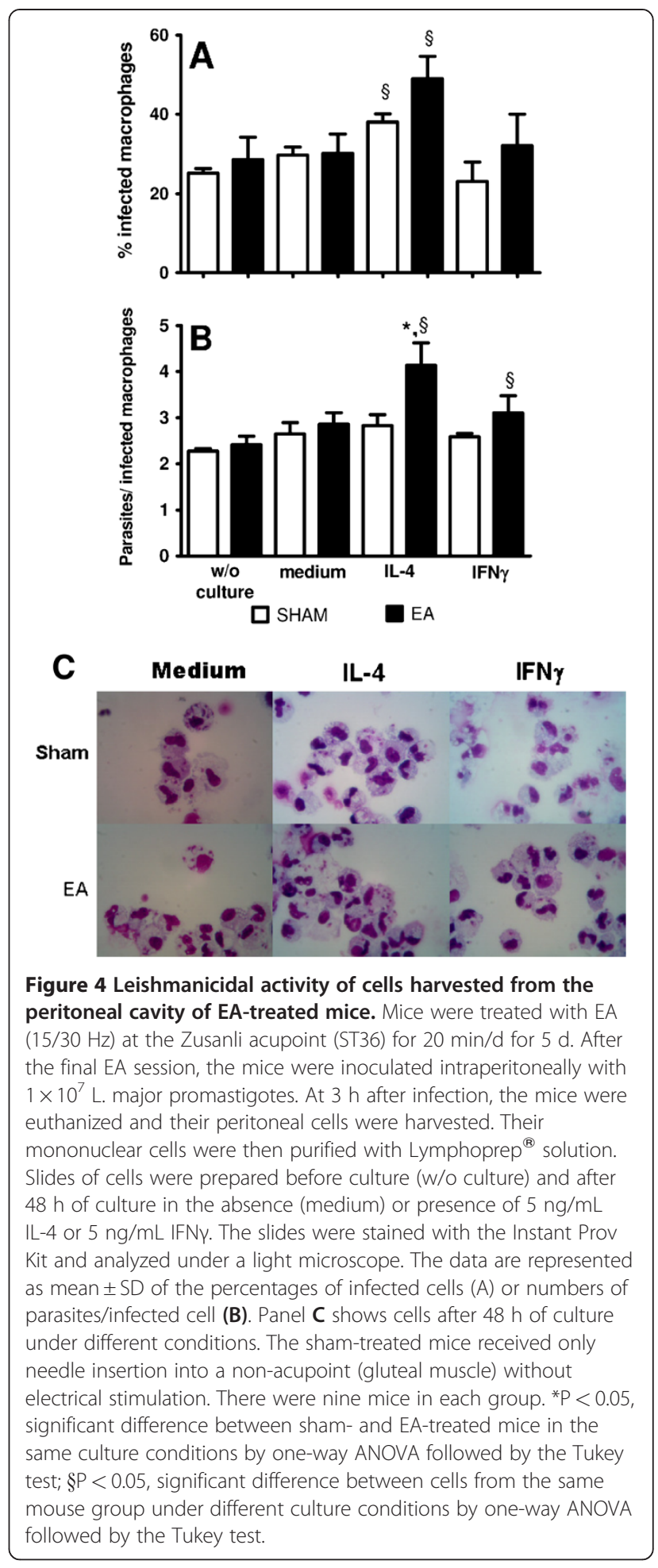

\section{EA increases L. major survival in vivo}

To verify whether the increased survival of parasites also occurred in vivo after EA treatment, we treated the mice with EA for $5 \mathrm{~d}$ and then immediately injected with promastigote parasites into the footpad at the end of the final EA treatment. The lesion size was significantly 


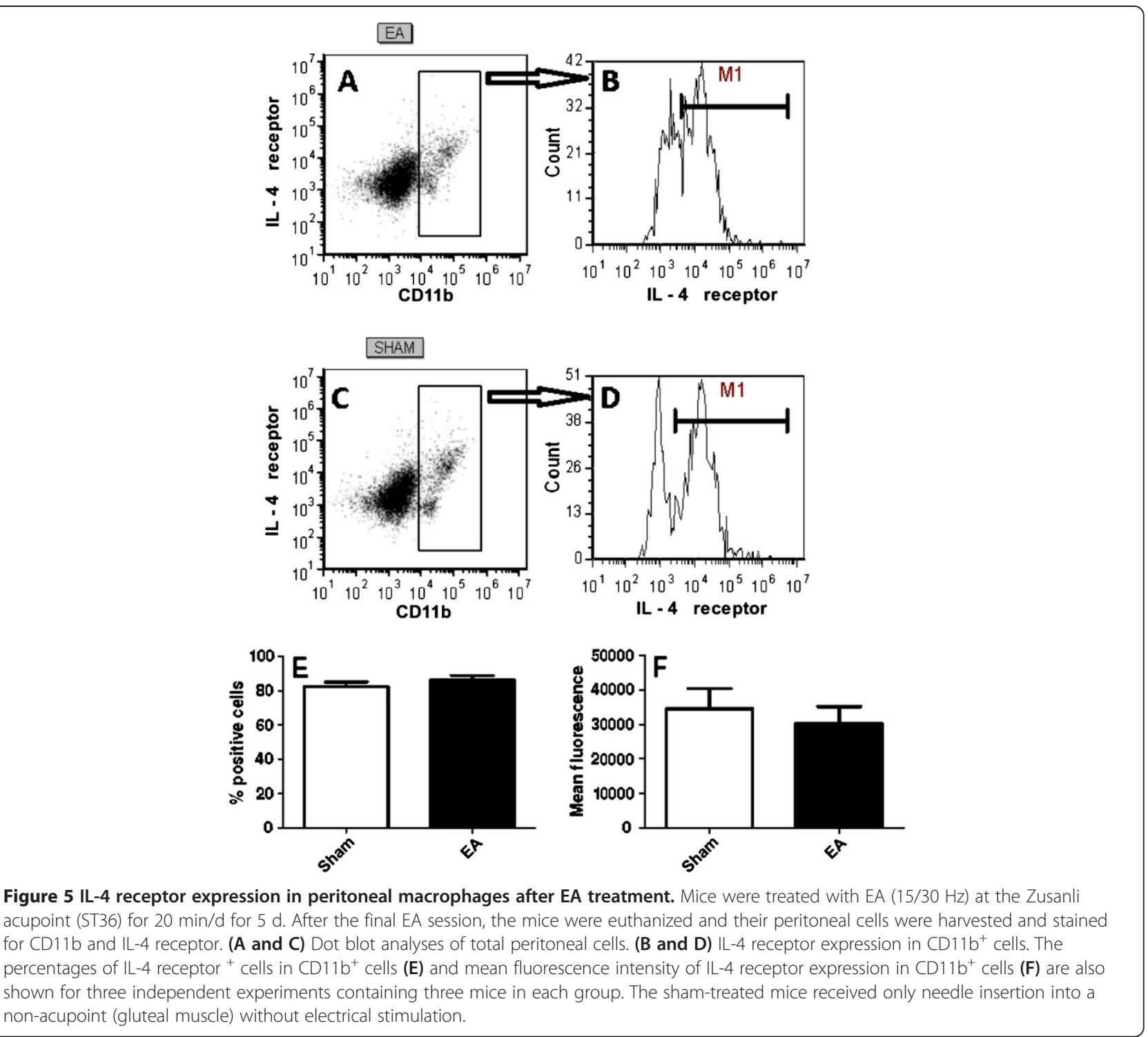

higher in EA-treated mice than in sham-treated mice $(\mathrm{P}=0.039)$.

\section{Discussion}

Macrophages have well-established roles in the primary responses to pathogens, and can be activated in different ways, giving rise to cMO or AAMo [12,14]. Arginase is the prototypic marker for AAMo [12,14]. This enzyme increases in murine macrophages involved in helminthic infection [14], tumors [22] and tissue repair [23], converting $\mathrm{L}$-arginine to ornithine and urea, while iNOS present in $\mathrm{cMO}$ converts $\mathrm{L}$-arginine to citrulline and NO [12]. Arginase and iNOS share the same substrate, leading to an inverse correlation between these two enzymes in helminthic infection, tumors and tissuerepair environments [14,22,23]. In our experiments, EA suppressed the NO production induced by LPS or LPS and IFN $\gamma$ in peritoneal macrophages. Although the arginase activity in cells after EA treatment or cultured in the absence of IL-4 did not change, the activity was increased in macrophages from EA-treated mice in the presence of IL-4. It is not clear how EA increases the IL4 responsiveness of macrophages, although EA and IL-4 could synergistically potentiate the responsiveness or interfere with some signal transduction from the IL-4 receptor. However, the mechanism is unlikely due to an increase in IL-4 receptor expression, because the IL-4 receptor expression was similar between macrophages from sham- and EA-treated mice.

The generation of AAMo with high arginase activity is associated with a decreased ability to control intracellular parasites such as L. major, while NO production by cMO is associated with better control of these parasites [15]. Experiments have been performed using IFN $\gamma$ - 


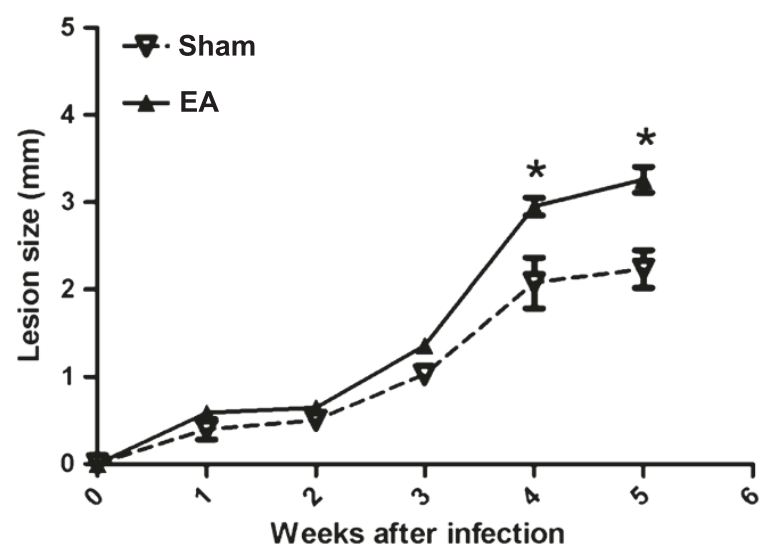

Figure 6 Lesions developed by sham- or EA-treated mice after L. major infection. BALB/C mice were treated with EA (15/30 Hz) at the Zusanli acupoint (ST36) for $20 \mathrm{~min} / \mathrm{d}$ for $5 \mathrm{~d}$. After the final EA session, the mice were infected with $2 \times 10^{6}$ stationary-phase promastigotes of L. major into one of the hind footpads. The lesion size was calculated as the difference between the left and right footpad measurements. The sham-treated mice received only needle insertion into a non-acupoint (gluteal muscle) without electrical stimulation. The data are represented as mean \pm SD of two independent experiments containing three mice in each group. ${ }^{*} \mathrm{P}<0.05$, significant difference between sham- and EA-treated mice by two-way ANOVA followed by a Tukey test.

stimulated macrophages to observe the killing of $\mathrm{L}$. major in vitro. In addition, IL-4 can prevent NO production and decrease the killing of the parasites $[15,24]$. These findings are in agreement with our results, showing an increase in the percentage of cells infected by L. major after IL-4 treatment. Macrophages from EA-treated mice were more responsive to IL-4 and enhanced the growth of the parasite inside the cells. An ability of IFN $\gamma$-stimulated macrophages to kill parasites was not observed in our experiments, possibly because the combination of LPS and IFN $\gamma$ is required to produce the optimal stimulation for NO production to kill parasites [24], and only IFN $\gamma$ was used in some of our experiments.

Infection of $\mathrm{BALB} / \mathrm{c}$ mice with $\mathrm{L}$. major induces early production of IL- 4 by $\mathrm{CD}^{+}{ }^{+} \mathrm{T}$ cells carrying the $\mathrm{V} \beta 4 \alpha 8 \mathrm{~T}$ cell receptor at $16 \mathrm{~h}$ after infection [25]. This early production of IL-4 and the presence of AAMo are associated with the susceptibility of this mouse strain to $\mathrm{L}$. major infection [15,25]. Since macrophages from EA-treated mice were more responsive to IL-4, the outcome of infecting mice with L. major was examined. The lesion size in EA-treated mice was more pronounced than that in sham-treated mice, suggesting that EA increases IL-4 responsiveness in vivo and interferes with the outcome of infection by intracellular pathogens such as L. major.

Electrical stimulation was not used in the shamtreated mice in our experiments. The experiments could rule out the effects of electrical current because of the small size of the mice. Electrical stimulation outside of an acupoint could travel to a nearby acupoint to produce effects with different intensities. The properties of acupoints include increased conductance and reduced impedance and resistance [26], and minimal electrical stimulation of an acupoint could provide significant effects in sham-treated mice [27].

Significant effects of EA were only observed when the mice were treated for $5 \mathrm{~d}$. The decreased effects of EA in the mice treated for $10 \mathrm{~d}$ could be caused by tolerance. EA tolerance was observed in rats treated with a polarized current for $30 \mathrm{~min} / \mathrm{d}$ for $6 \mathrm{~d}$ at the frequency of $100 \mathrm{~Hz}[28,29]$.

The anti-inflammatory properties of the ST36 acupoint have been examined in previous studies [5-9]. Our findings demonstrated that EA increased the IL-4 responsiveness of macrophages. In addition, our experiments showed a decrease in the microbicidal activity associated with the generation of AAMo.

\section{Conclusion}

EA at the ST36 acupoint in mice increases the IL-4 responsiveness of macrophages, generation of AAMo and susceptibility to L. major infection.

\section{Abbreviations \\ EA: Electroacupuncture; AAMo: Alternatively activated macrophages; ST36: Zusanli acupoint; NO: Nitric oxide; IL: Interleukin; IFNy: Interferon-ү; LPS: Lipopolysaccharide; CRH: Corticotropin-releasing hormone; TNF: Tumor necrosis factor; PBS: Phosphate-buffered saline; CMO: Classically activated macrophages; iNOS: Induced nitric oxide synthase; NGS: Normal goat serum; SD: Standard deviation.}

\section{Competing interests}

The authors declare that they have no competing interests.

\section{Authors' contributions}

DNA and MAPO conceived and designed the study. DNA performed the acupuncture. MMS, LFB and FDT performed the evaluations of arginase activity and nitric oxide production. WVP and CMG performed the evaluation 
of leishmanicidal activity in vitro and in vivo. All authors read and approved the final manuscript.

\section{Acknowledgments}

This study was supported by grants from the Coordenação de Aperfeiçoamento de Pesquisa de Pessoal de Nível Superior (CAPES) and Conelho Nacional de Desenvolvimento Científico e Tecnológico (CNPq)and by a fellowship from Fundação de Amparo a Pesquisa do Estado de Goias (FAPEG). We acknowledge Dr. Fatima Ribeiro-Dias for reviewing the manuscript.

Received: 18 November 2011 Accepted: 12 July 2012

Published: 28 July 2012

\section{References}

1. Zijlstra FJ, van den Berg-de Lange I, Huygen FJ, Klein J: Anti-inflammatory actions of acupuncture. Mediators Inflamm 2003, 12:59-69.

2. Kavoussi B, Ross BE: The neuroimmune basis of anti-inflammatory acupuncture. Integr Cancer Ther 2007, 6:251-257.

3. Cabioglu MT, Cetin BE: Acupuncture and immunomodulation. Am J Chin Med 2008, 36:25-36.

4. Cho ZH, Hwang SC, Wong EK, Son YD, Kang CK, Park TS, Bai SJ, Kim YB, Lee $Y B$, Sung KK, et al: Neural substrates, experimental evidences and functional hypothesis of acupuncture mechanisms. Acta Neurol Scand 2006, 113:370-377.

5. Tian L, Huang YX, Tian M, Gao W, Chang Q: Downregulation of electroacupuncture at ST36 on TNF-alpha in rats with ulcerative colitis. World J Gastroenterol 2003, 9:1028-1033.

6. Wang WJ, Lu J, Niu CS, Huang YR, Ma Q, YG A, Hao HW, Li LM, Tu Y: [Effects of electroacupuncture of unilateral and bilateral "zusanli" (ST 36) on serum TNF-alpha, IL-1 and IL-4 levels in rats with chronic inflammatory pain]. Zhen Ci Yan Jiu 2008, 35:429-432.

7. He TF, Yang WJ, Zhang SH, Zhang CY, Li LB, Chen YF: Electroacupuncture inhibits inflammation reaction by upregulating vasoactive intestinal Peptide in rats with adjuvant-induced arthritis. Evid Based Complement Alternat Med 2011, 290489

8. $\quad$ Fang JQ, Shao XM, Ma GZ: Effect of electroacupuncture at "Zusanli" (ST 36) and "Sanyinjiao" (SP 6) on collagen-induced arthritis and secretory function of knee-joint synoviocytes in rats. Zhen Ci Yan Jiu 2009, 34:93-96.

9. Chae Y, Hong MS, Kim GH, Hahm DH, Park HJ, Ha E, Kim MJ, Yang J, Lee H: Protein array analysis of cytokine levels on the action of acupuncture in carrageenan-induced inflammation. Neurol Res 2007, 29(Suppl 1):S55-S58.

10. Takahashi N, de Jager VC, Gluck A, Letzkus M, Hartmann N, Staedtler F, Ribeiro-Dias F, Heuvelmans-Jacobs M, van den Berg WB, Joosten LA: The molecular signature of oxidative metabolism and the mode of macrophage activation determine the shift from acute to chronic disease in experimental arthritis: critical role of interleukin-12p40. Arthritis Rheum 2008, 58:3471-3484.

11. Hunter MM, Wang A, Parhar KS, Johnston MJ, Van Rooijen N, Beck PL, McKay DM: In vitro-derived alternatively activated macrophages reduce colonic inflammation in mice. Gastroenterology 2010, 138:1395-1405.

12. Martinez FO, Helming L, Gordon S: Alternative activation of macrophages: an immunologic functional perspective. Annu Rev Immunol 2009, 27:451483.

13. Zhang $X$, Mosser DM: Macrophage activation by endogenous danger signals. J Pathol 2008, 214:161-178.

14. Maizels RM, Pearce EJ, Artis D, Yazdanbakhsh M, Wynn TA: Regulation of pathogenesis and immunity in helminth infections. J Exp Med 2009, 206:2059-2066.

15. Kropf P, Fuentes JM, Fahnrich E, Arpa L, Herath S, Weber V, Soler G, Celada A, Modolell M, Muller I: Arginase and polyamine synthesis are key factors in the regulation of experimental leishmaniasis in vivo. FASEB J 2005, 19:1000-1002.

16. Liew FY, O'Donnell CA: Immunology of leishmaniasis. Adv Parasitol 1993, 32:161-259.

17. Biswas A, Bhattacharya A, Kar S, Das PK: Expression of IL-10-triggered STAT3-dependent IL-4Ralpha is required for induction of arginase 1 in visceral leishmaniasis. Eur J Immunol 2011, 41:992-1003.

18. Kim SK, Lee Y, Cho H, Koo S, Choi SM, Shin MK, Hong MC, Min BI, Bae H: A Parametric Study on the Immunomodulatory Effects of
Electroacupuncture in DNP-KLH Immunized Mice. Evid Based Complement Alternat Med 2011, 389063.

19. Yim YK, Lee H, Hong KE, Kim Yl, Lee BR, Son CG, Kim JE: Electroacupuncture at acupoint ST36 reduces inflammation and regulates immune activity in Collagen-Induced Arthritic Mice. Evid Based Complement Alternat Med 2007, 4:51-57.

20. Corraliza IM, Campo ML, Soler G, Modolell M: Determination of arginase activity in macrophages: a micromethod. J Immunol Methods 1994, 174:231-235.

21. Green SJ, Crawford RM, Hockmeyer JT, Meltzer MS, Nacy CA: Leishmania major amastigotes initiate the L-arginine-dependent killing mechanism in IFN-gamma-stimulated macrophages by induction of tumor necrosis factor-alpha. J Immunol 1990, 145:4290-4297.

22. Munder M: Arginase: an emerging key player in the mammalian immune system. Br J Pharmacol 2009, 158:638-651.

23. Daley JM, Brancato SK, Thomay AA, Reichner JS, Albina JE: The phenotype of murine wound macrophages. J Leukoc Biol 2010, 87:59-67.

24. Holscher C, Arendse B, Schwegmann A, Myburgh E, Brombacher F: Impairment of alternative macrophage activation delays cutaneous leishmaniasis in nonhealing BALB/c mice. J Immunol 2006, 176:1115-1121.

25. Launois P, Maillard I, Pingel S, Swihart KG, Xenarios I, Acha-Orbea $H$, Diggelmann H, Locksley RM, MacDonald HR, Louis JA: IL-4 rapidly produced by $\mathrm{V}$ beta $4 \mathrm{~V}$ alpha $8 \mathrm{CD} 4+\mathrm{T}$ cells instructs Th2 development and susceptibility to Leishmania major in BALB/c mice. Immunity 1997, 6:541-549.

26. Ahn AC, Martinsen OG: Electrical characterization of acupuncture points: technical issues and challenges. J Altern Complement Med 2007, 13:817824.

27. Lundeberg T, Lund I, Sing A, Naslund J: Is Placebo Acupuncture What It is Intended to Be? Evid Based Complement Alternat Med 2011, 932407.

28. Tian JH, Zhang W, Fang Y, Xu W, Grandy DK, Han JS: Endogenous orphanin FQ: evidence for a role in the modulation of electroacupuncture analgesia and the development of tolerance to analgesia produced by morphine and electroacupuncture. Br J Pharmacol 1998, 124:21-26.

29. Ulett GA, Han S, Han JS: Electroacupuncture: mechanisms and clinical application. Biol Psychiatry 1998, 44:129-138.

doi:10.1186/1749-8546-7-17

Cite this article as: Aguiar et al: Electroacupuncture at the ST36 acupoint increases interleukin-4 responsiveness in macrophages, generation of alternatively activated macrophages and susceptibility to Leishmania major infection. Chinese Medicine 2012 7:17.

\section{Submit your next manuscript to BioMed Central and take full advantage of:}

- Convenient online submission

- Thorough peer review

- No space constraints or color figure charges

- Immediate publication on acceptance

- Inclusion in PubMed, CAS, Scopus and Google Scholar

- Research which is freely available for redistribution 